University of Nebraska - Lincoln

DigitalCommons@University of Nebraska - Lincoln

2010

\title{
Abandoned Mine Drainage in the Swatara Creek Basin, Southern Anthracite Coalfield, Pennsylvania, USA: 2. Performance of Treatment Systems
}

Charles A. Cravotta III

US Geological Survey, PA Water Science Center, 215 Limekiln Rd, New Cumberland, PA, USA,

cravotta@usgs.gov

Follow this and additional works at: https://digitalcommons.unl.edu/usgsstaffpub

Part of the Earth Sciences Commons

Cravotta III, Charles A., "Abandoned Mine Drainage in the Swatara Creek Basin, Southern Anthracite Coalfield, Pennsylvania, USA: 2. Performance of Treatment Systems" (2010). USGS Staff -- Published Research. 304.

https://digitalcommons.unl.edu/usgsstaffpub/304

This Article is brought to you for free and open access by the US Geological Survey at DigitalCommons@University of Nebraska - Lincoln. It has been accepted for inclusion in USGS Staff -- Published Research by an authorized administrator of DigitalCommons@University of Nebraska - Lincoln. 


\title{
Abandoned Mine Drainage in the Swatara Creek Basin, Southern Anthracite Coalfield, Pennsylvania, USA: 2. Performance of Treatment Systems
}

\author{
Charles A. Cravotta III
}

Received: 14 September 2009/ Accepted: 5 April 2010

(C) US Government 2010

\begin{abstract}
A variety of passive and semi-passive treatment systems were constructed by state and local agencies to neutralize acidic mine drainage (AMD) and reduce the transport of dissolved metals in the upper Swatara Creek Basin in the Southern Anthracite Coalfield in eastern Pennsylvania. To evaluate the effectiveness of selected treatment systems installed during 1995-2001, the US Geological Survey collected water-quality data at upstream and downstream locations relative to each system eight or more times annually for a minimum of 3 years at each site during 19962007. Performance was normalized among treatment types by dividing the acid load removed by the size of the treatment system. For the limestone sand, open limestone channel, oxic limestone drain, anoxic limestone drain (ALD), and limestone diversion well treatment systems, the size was indicated by the total mass of limestone; for the aerobic wetland systems, the size was indicated by the total surface area of ponds and wetlands. Additionally, the approximate cost per tonne of acid treated over an assumed service life of 20 years was computed. On the basis of these performance metrics, the limestone sand, ALD, oxic limestone drain, and limestone diversion wells had similar ranges of acid-removal efficiency and cost efficiency. However, the open limestone channel had lower removal efficiency and higher cost per ton of acid treated. The wetlands effectively attenuated metals transport but were relatively expensive considering metrics that evaluated acid removal and cost efficiency. Although the
\end{abstract}

Electronic supplementary material The online version of this article (doi:10.1007/s10230-010-0113-5) contains supplementary material, which is available to authorized users.

C. A. Cravotta III ( $\square)$

USGS Pennsylvania Water Science Center, New Cumberland, PA 17070, USA

e-mail: cravotta@usgs.gov water-quality data indicated that all treatments reduced the acidity load from AMD, the ALD was most effective at producing near-neutral $\mathrm{pH}$ and attenuating acidity and dissolved metals. The diversion wells were effective at removing acidity and increasing $\mathrm{pH}$ of downstream water and exhibited unique potential to treat moderate to high flows associated with storm flow conditions.

Keywords Coal mines - Diversion well $\cdot$ Limestone sand · Limestone channel $\cdot$ Limestone drain $\cdot$ Wetland

\section{Introduction}

Acidic mine drainage (AMD) commonly is treated near the point of origin to neutralize acidity and remove dissolved and suspended pollutants before it reaches a stream. Conventional active treatment of AMD involves the addition of caustic chemicals, such as sodium hydroxide $(\mathrm{NaOH})$ or hydrated lime $\left(\mathrm{Ca}(\mathrm{OH})_{2}\right)$, to increase $\mathrm{pH}$ and remove dissolved metals (Skousen et al. 1998). Alternatively, passive and semi-passive AMD treatment systems include anaerobic and aerobic wetlands and various limestone-based systems, such as anoxic or oxic limestone drains, open limestone channels, limestone diversion wells, and vertical flow compost wetlands (Hedin et al. 1994a; Skousen et al. 1998; Watzlaf et al. 2004; Ziemkiewicz et al. 2003). These passive and semi-passive systems generally are limited by slower rates of neutralization and pollutant removal than active treatment systems but can be cost effective where water chemistry meets suggested criteria and where land and component materials are locally available (Ziemkiewicz et al. 2003). If direct treatment of the AMD is not feasible, $\mathrm{pH}$ adjustment of the stream water may be effective to meet downstream aquatic-quality goals. 
Various passive and semi-passive treatment systems have different advantages and disadvantages, and suffer from possible complications associated with variability of flow rates and chemistry of the AMD, and from uncertainties about efficiency and longevity of the treatment. Furthermore, every site requiring treatment has unique environmental characteristics. In general, passive treatment systems are effective for treating 'typical' flow and waterquality conditions (Skousen et al. 1998; Ziemkiewicz et al. 2003), though treatment effectiveness and downstream benefits may diminish as conditions deviate from normal. For example, the performance of a treatment system could decline with increased flow rate during runoff events because of decreased retention time and/or increased contaminant load. However, treatment performance for a wide range of flow conditions is poorly documented in the literature.

This paper evaluates the effectiveness of passive and semi-passive treatment systems for neutralizing acidity and removing metals and other pollutants from AMD and affected stream water in the upper Swatara Creek Basin in eastern Pennsylvania. Data collected by the US Geological Survey (USGS) over a wide range of flow conditions during June 1996 through June 2007 at AMD treatment sites within and immediately downstream of the mined area above Ravine, Pa. (Fig. 1), were used for this evaluation. A companion paper (Cravotta et al. 2010) evaluates the downstream water-quality trends and recovery of fish populations within affected stream reaches during the study period.

\section{Description of Treatment Systems}

During 1995-2008, various passive and semi-passive treatment systems were installed at selected locations to neutralize the AMD or the stream water at downstream sites (Figs. 1, 2). Where access and space were available, the treatment systems were located immediately below the AMD source (anoxic limestone drain, oxic limestone drain, aerobic wetland); otherwise, the systems were located within the downstream reach (limestone sand, open limestone channel, limestone diversion wells) of the affected stream (Table 1). The treatment systems were installed and maintained by the Schuylkill Conservation District and the Northern Swatara Creek Watershed Association. Technical and financial support for the design, construction, and monitoring of the treatment systems were provided by the Pennsylvania Department of Environmental Protection (PaDEP), US Department of Energy (USDOE), and USGS.

Limestone-sand dosing and open limestone channels (Fig. 2a) are relatively simple passive treatment systems where limestone is added once or infrequently to the streambed or AMD discharge channel (Skousen et al. 1998; Ziemkiewicz et al. 1997). Generally, these treatment methods were selected to add alkalinity downstream of inaccessible or diffuse AMD sources that were mildly acidic and had relatively low concentrations of dissolved $\mathrm{Al}$ and $\mathrm{Fe}(<2 \mathrm{mg} / \mathrm{L})$. Although average residence time in the treated reach would be less than $5 \mathrm{~min}$, particles transported downstream could continue to dissolve. Forty tonnes ( $\mathrm{t})$ of limestone sand $(<0.5 \mathrm{~cm}$ diameter $)$, which can
Fig. 1 Locations of waterquality and streamflow monitoring sites relative to major AMD sources and associated treatment systems in the upper Swatara Creek Basin within the Southern Anthracite Coalfield, above Ravine (See Cravotta et al. 2010, Fig. 1a for location of map area). Year of implementation of treatment is indicated in parentheses.

Monitoring site identification number (for example, E3-1) is indicated only for sites discussed in this paper. Monitoring sites are listed in Table 1

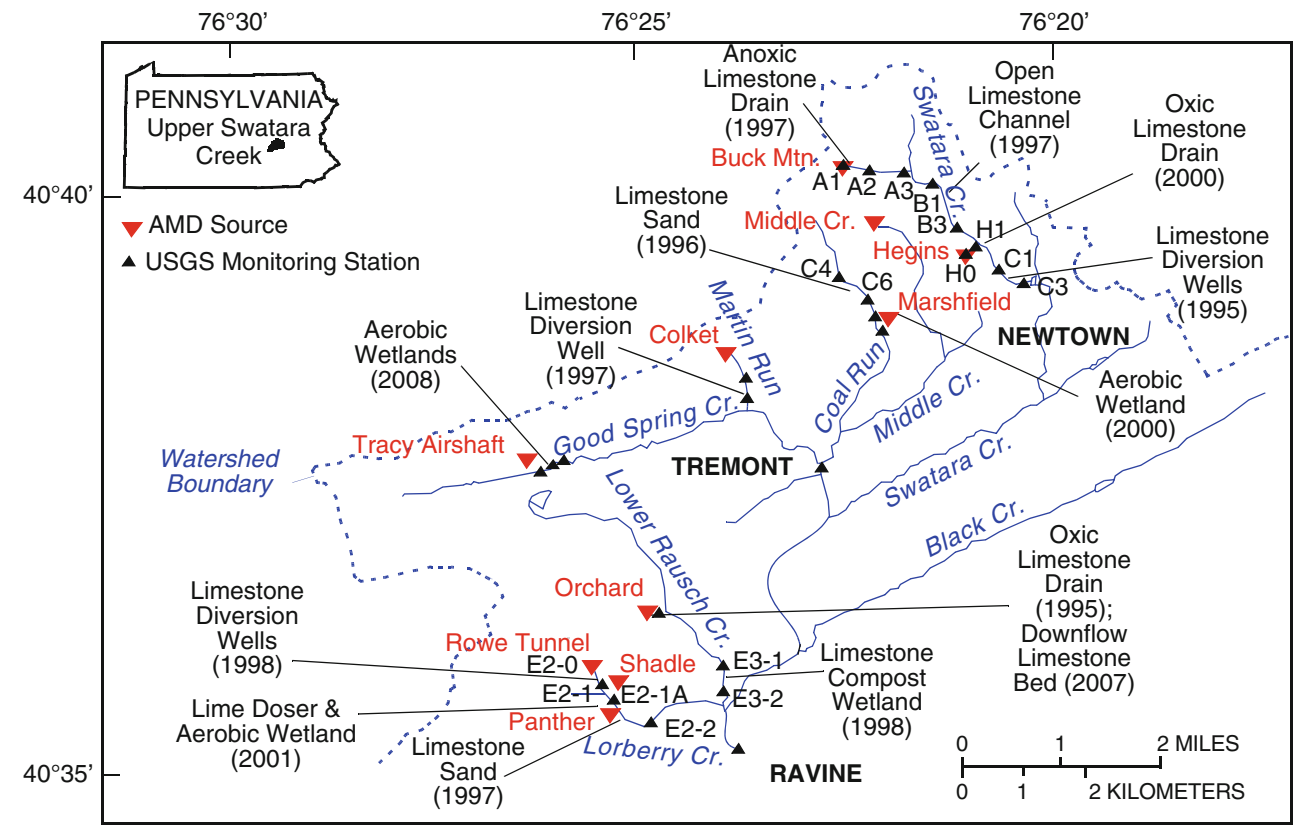


Fig. 2 Schematic illustrations of passive treatment systems installed in the upper Swatara Creek Basin, 1995-2008: a open limestone channel; b limestone diversion well; $\mathbf{c}$ anoxic or oxic limestone drain; and $\mathbf{d}$ limestone or compost based wetland. Although generalized, the illustration for a applies specifically to the upper Swatara Creek, that for c to treatment on the Buck Mountain discharge, and that for d to treatment on Lower Rausch Creek
A

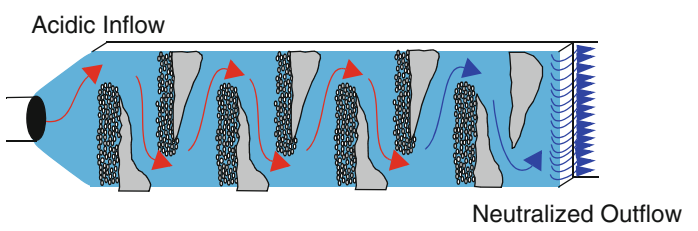

B

Limestone, $4-9 \mathrm{~cm}$

$\square$ Limestone sand, $0.03-0.6 \mathrm{~cm}$

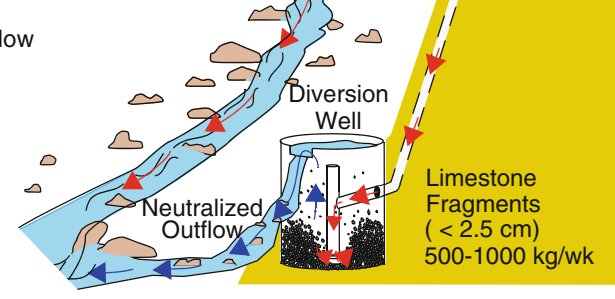

C $_{\text {Monitoring }}$

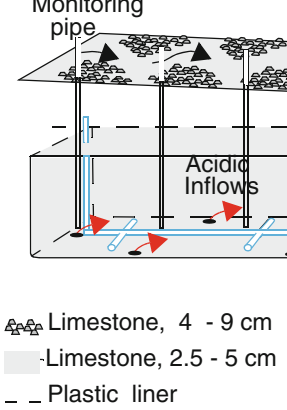

Land surface

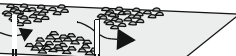

D

Neutralized Outflow
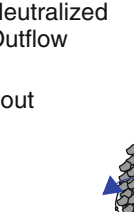

All piping within

drain is perforated)

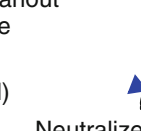

Neutraliz
Outflow

$\because$ Mushroom compost

Limestone, 9 - $30 \mathrm{~cm}$

Table 1 Acidic mine drainage treatment systems and associated water-quality monitoring sites, upper Swatara Creek Basin, Schuylkill County, Pennsylvania; treatment system and monitoring site locations are shown in Fig. 1

\begin{tabular}{|c|c|c|c|c|}
\hline \multirow{2}{*}{$\begin{array}{l}\text { Treatment } \\
\text { system }\end{array}$} & \multirow[t]{2}{*}{ Description } & \multirow{2}{*}{$\begin{array}{l}\text { Year of installation/ } \\
\text { expansion }\end{array}$} & \multicolumn{2}{|c|}{ Monitoring site ID } \\
\hline & & & Upstream & Downstream \\
\hline LSC & Limestone sand in Coal Run below Middle Creek discharges & 1996 & $\mathrm{C} 4$ & C6 \\
\hline OLS & $\begin{array}{l}\text { Open limestone channel on Swatara Cr below Buck Mountain } \\
\text { discharge }\end{array}$ & 1997 & B1 & B3 \\
\hline $\mathrm{ODH}$ & Oxic limestone drain on Hegins discharge & 2000,2005 & HO & H1 \\
\hline ADB & Anoxic limestone drain on Buck Mountain discharge & $1997,2001,2005$ & A1 & $\mathrm{A} 2$ and $\mathrm{A} 3$ \\
\hline DWS & Limestone diversion wells on Swatara Creek below Hegins discharge & 1995 & $\mathrm{C} 1$ & $\mathrm{C} 3$ \\
\hline DWL & $\begin{array}{l}\text { Limestone diversion wells on Lorberry Creek below Rowe Tunnel } \\
\text { discharge }\end{array}$ & 1998 & E2-0 & E2-1 \\
\hline WLL & Aerobic wetlands beside Lorberry Creek below Rowe Tunnel discharge & 2001 & E2-1A & E2-2 \\
\hline WLR & $\begin{array}{l}\text { Limestone-compost wetlands on Lower Rausch Cr below Orchard } \\
\text { discharge }\end{array}$ & 1998 & E3-1 & E3-2 \\
\hline
\end{tabular}

dissolve rapidly because of its small grain size and surface area, were dumped once from trucks directly into Coal Run downstream from the Middle Creek discharges, between sites C4 and C6, in September 1996, and $136 \mathrm{t}$ were dumped into an unnamed tributary of Lorberry Creek below the Pantherhead discharge in February 1997 (Fig. 1). An open limestone channel was constructed in March 1997 within a $33.5 \mathrm{~m}$ long segment of Swatara Creek, between sites B1 and B3 (Fig. 1), below the confluence of acidic headwaters of Swatara Creek and the unnamed tributary that originated at the Buck Mountain discharge. To construct the open limestone channel, a total of $40 \mathrm{t}$ of sand-size limestone fragments and $63 \mathrm{t}$ of cobble-size fragments $(3-11 \mathrm{~cm})$ were installed as a series of alternating berms extending part way across the 4.6-m wide channel from opposite sides of the stream (Fig. 2a).

An anoxic limestone drain (ALD) (Fig. 2c) is another relatively simple passive-treatment method that involves the burial of cobble-size limestone aggregate in trenches that intercept acidic water before it emerges from the ground (Cravotta and Trahan 1999; Hedin et al. 1994a, b; Skousen et al. 1998). Generally, alkalinity production in 
enclosed limestone drains is greater than that for open limestone systems (Cravotta 2003). Thus, if concentrations of dissolved $\mathrm{Al}$ and $\mathrm{Fe}^{3+}$ were low to moderate $(<5 \mathrm{mg} / \mathrm{L})$ and if space was accessible to install the limestone bed at the AMD source, ALDs were the preferred treatment method in the Swatara Creek watershed. Limestone drains designed for a typical retention time of $6 \mathrm{~h}$ were constructed in March 1995 at the Orchard discharge to treat a small oxic discharge (38-113 L/s; $40 \mathrm{t}$ of limestone) along Lower Rausch Creek; in May 1997 at the Buck Mountain discharge (site A1) to treat a large, anoxic discharge $(189-756 \mathrm{~L} / \mathrm{s} ; 320 \mathrm{t}$ of limestone) at the headwaters of Swatara Creek; and in June 2000 at the Hegins discharge (site H0) to treat a large oxic discharge $(378-1,890 \mathrm{~L} / \mathrm{s}$; $727 \mathrm{t}$ of limestone) near the headwaters of Swatara Creek (Figs. 1, 2).

The limestone beds at the Orchard and Buck Mountain discharges were buried to minimize exchange with the atmosphere. Keeping $\mathrm{CO}_{2}$ within the limestone bed can enhance limestone dissolution and alkalinity production (Cravotta 2003; Cravotta and Trahan 1999). Keeping $\mathrm{O}_{2}$ out of contact with the influent AMD minimizes the potential for oxidation of $\mathrm{Fe}^{2+}$ and the consequent precipitation of $\mathrm{Fe}^{\mathrm{III}}$ oxyhydroxide on the limestone surfaces or between particles. Although allowing $\mathrm{O}_{2}$ into the limestone bed can facilitate the removal of $\mathrm{Fe}, \mathrm{Mn}$, and trace metals and accelerate limestone dissolution, the accumulation of Fe-rich solids can lead to clogging (Cravotta and Trahan 1999; Cravotta et al. 2004). Perforated flushing pipes were installed within the limestone bed at the Buck Mountain and Hegins discharges to facilitate the removal of precipitated $\mathrm{Fe}^{\mathrm{III}}$ and $\mathrm{Al}$ oxyhydroxides.

Because monitoring indicated substantial limestone dissolution, the ALD on the Buck Mountain discharge was supplemented twice, in January 2001 and September 2005, with $91 \mathrm{t}$ of limestone. Additionally, in September 2005, the oxic limestone drain on the Hegins discharge was enlarged with the addition of $182 \mathrm{t}$ of limestone and covered with approximately $0.15 \mathrm{~m}$ of leaf-litter compost. The enlargement and compost cover were intended to increase retention time, retain $\mathrm{CO}_{2}$, and promote greater rates of limestone dissolution. Lastly, in August 2007, the oxic limestone drain on the Orchard discharge, which had been out of service since 2000, was completely reconstructed as an up-flow treatment system with flushing pipes and a settling basin to manage the accumulation of metal-rich solids. The latter modifications were implemented after monitoring for the subject paper had been completed, so this treatment system is not described further.

In a limestone diversion well (Fig. 2b), acidic stream water or AMD is diverted from an upstream site into a pipe, and the hydraulic force at the terminus of the pipe is deflected upward through limestone aggregate inside $1.2-\mathrm{m}$ diameter 'wells' (Arnold 1991). Generally, if the AMD source was net acidic with moderate or elevated concentrations of dissolved $\mathrm{O}_{2}, \mathrm{Al}$, or $\mathrm{Fe}^{3+}(>2 \mathrm{mg} / \mathrm{L})$ and if space was limited for construction of a treatment system, limestone diversion wells were installed at an accessible downstream location. As much as $1 \mathrm{t}$ of limestone can be consumed weekly by each operating diversion well, requiring regular replenishment of the limestone in this semi-passive system. Hydraulic churning within the diversion well abrades the limestone to fine particles and prevents encrustation by $\mathrm{Fe}^{\mathrm{III}}$ or $\mathrm{Al}$ oxyhydroxides. Dissolution of limestone within and downstream of the diversion well promotes increases in the $\mathrm{pH}$ and alkalinity of the stream. In addition to pulverized limestone, $\mathrm{Fe}^{\mathrm{III}}$ and Al oxyhydroxides may precipitate and accumulate downstream of the diversion wells. In November 1995, a pair of diversion wells was installed to treat water diverted from the headwaters of Swatara Creek below site C1; in July 1997, a single diversion well was installed to treat water downstream from the Colket discharge on Martin Run below site C7; and in December 1998, a pair of diversion wells was installed to treat water downstream from the Rowe Tunnel discharge below site E2-0 near the headwaters of Lorberry Creek (Fig. 1). Because the Martin Run diversion well clogged repeatedly and was rarely working during the subject investigation, this treatment system is not described further.

Constructed wetlands or settling ponds are a typical component of most AMD treatment systems that promote the precipitation and deposition of $\mathrm{Fe}$ and other metals (Cravotta 2007; Hedin et al. 1994a; Skousen et al. 1998). For net-alkaline water, aerobic ponds and wetlands that facilitate the oxidation of $\mathrm{Fe}^{2+}$ and the settling of $\mathrm{Fe}^{\mathrm{III}}$ oxyhydroxides can be appropriate. For net-acidic water, wetlands that have compost and/or limestone substrates (Fig. 2d) can be useful to add alkalinity and remove dissolved metals. The organic matter in the compost provides a substrate for plant rooting and for microbial reduction of $\mathrm{SO}_{4}$. During 1997-2008, four wetlands were constructed to reduce the downstream transport of suspended metal-rich particles in the upper Swatara Creek Basin. In December 1997, near the mouth of Lower Rausch Creek at site E3 (Fig. 1), a 0.93-ha limestone-compost-based wetland was constructed to remove metals from stream flow that commonly had near-neutral $\mathrm{pH}$ but had potential to be net acidic during storm flow conditions (Koury and Hellier 1999). The Lower Rausch Creek wetlands were constructed downstream from the outflow of the Orchard oxic limestone drain built in 1995 (Fig. 1, site E3-S0). Additionally, in December 2001, a 0.49-ha wetland was constructed adjacent to Lorberry Creek at station E2-1 (Fig. 1). The Lorberry Creek wetland was constructed to remove iron from treated water exiting the two limestone diversion 
wells below the Rowe Tunnel discharge. Because the effluent from the Rowe Tunnel had widely variable $\mathrm{pH}$, acidity, and metals concentrations, a hydrated lime doser was installed at the wetlands inflow to supplement the treatment by the diversion wells. Lastly, to treat the netalkaline AMD from the Marshfield discharge along Coal Run and from the Tracy Airshaft discharge along Good Spring Creek, aerobic wetlands were constructed at these sites in June 2000 and May 2008, respectively. Because monitoring of the Marshfield and Tracy wetlands was not conducted as part of the subject investigation, these treatment systems are not described further.

\section{Methods}

To document variations in untreated AMD, treatmentsystem performance, and cumulative downstream effects of AMD treatment monitoring sites were established upstream and downstream of each treatment and along lower reaches of Swatara Creek (Fig. 1). Fixed-interval grab samples (4-or 6-week intervals) were collected over a range of hydrologic conditions from well-mixed zones at the stream and AMD monitoring sites. Instantaneous data on flow rate, temperature, specific conductance ( $\mathrm{SC}$ ), $\mathrm{pH}$, redox potential (Eh), and dissolved oxygen (DO) were measured when water-quality samples were collected. To minimize waterquality effects from aeration, AMD samples were collected and electrodes were immersed as close as possible to the point of discharge.

Whole-water subsamples were analyzed in the laboratory for alkalinity to $\mathrm{pH} 4.5$ endpoint (American Public Health Association 1998a) within $24 \mathrm{~h}$ of sampling, whereas hot-peroxide acidity (American Public Health Association 1998b), total constituent concentrations, and 'dissolved' ( $0.45 \mu \mathrm{m}$ pore-size filter) constituent concentrations were analyzed within 3 months of sampling. Because hot-peroxide acidity values obtained for this study did not include results for negative values, the net acidity was computed considering positive contributions from $\mathrm{H}^{+}$ $(\mathrm{pH})$ and concentrations of dissolved iron, manganese, and aluminum in $\mathrm{mg} / \mathrm{L}\left(\mathrm{C}_{\mathrm{Fe}}, \mathrm{C}_{\mathrm{Mn}}, \mathrm{C}_{\mathrm{Al}}\right.$, respectively) as:

$$
\begin{aligned}
& \mathrm{Net} \operatorname{Acidity}\left(\mathrm{mg} / \mathrm{L} \mathrm{CaCO}_{3}\right)=50\left(10^{(3-\mathrm{pH})}\right) \\
& \left.+2 \mathrm{C}_{\mathrm{Fe}}{ }^{2+} / 55.85+2 \mathrm{C}_{\mathrm{Mn}} / 54.94+3 \mathrm{C}_{\mathrm{Al}} / 26.98\right) \\
& - \text { Alkalinity }
\end{aligned}
$$

Kirby and Cravotta (2005) showed that net acidity computed with Eq. 1 is comparable in value to the standard method hot peroxide acidity (American Public Health Association 1998b). They also showed that if the AMD is net acidic (net acidity $>0$; hot-peroxide acidity $>0$ ), the ultimate $\mathrm{pH}$ of oxidized samples will be less than 5.0; however, if the AMD is net alkaline (net acidity $<0$; hot-peroxide acidity $<0$ ), the ultimate $\mathrm{pH}$ of the oxidized AMD will be maintained at values greater than or equal to 6.0 .

The computed net acidity and associated hydrochemical data for influent and effluent samples or upstream and downstream samples for eight individual treatment systems (Table 1) were compared to evaluate performance. If multiple samples were collected on a given date at a site, the daily average values were used. To provide temporal context for variable hydrologic conditions and seasonality, the upstream and downstream data for flow rate and water quality were illustrated as time-series plots. The overall effects of treatment were indicated by the differences between pairedsample (downstream-upstream) data values for the different treatment systems during the post-implementation period. Boxplots were used to display the water-quality data for AMD sources and the downstream-upstream differences for each treatment system.

The Wilcoxon matched-pairs signed-rank test (Helsel and Hirsch 2002) was used to indicate the significance of differences in water quality between upstream and downstream sites. The significance results of the signed-rank test were displayed as equality or inequality symbols above the boxplots showing the actual difference values between upstream and downstream data for each treatment. If the mean rank difference between the downstream site and the upstream site was insignificant at a probability level of 0.10 , the difference would be equal to zero (=). On the other hand, the treatment effects would be considered significant if the mean rank difference was positive $(>)$ or negative $(<)$ at a probability level of 0.10 . Furthermore, to indicate possible variability in treatment performance as a function of the hydrologic conditions, the rank differences also were evaluated for low-, normal-, and high-flow subsets. If stream flow of Swatara Creek at Ravine on the date of sampling was less than the 25 th percentile for the study period, the sample was classified as low-flow; between the 25th and 75th percentiles, the sample was classified as normal-flow; or greater than the 75th percentile, the sample was classified as high-flow.

Data on treatment-system performance were normalized for comparison among different systems considering the acid-removal rate relative to the size and cost of the treatment system. In accordance with methods used by Ziemkiewicz et al. (2003) for 83 different treatment systems in the eastern US, the acid-removal efficiency was computed as the median acid load removed (influent netacidity load-effluent net-acidity load, in g/day as $\mathrm{CaCO}_{3}$ ) divided by the size of the treatment system. The size of wetland systems was indicated by the total surface area (in $\mathrm{m}^{2}$ ) of ponds and wetlands; in contrast, the size of limestone systems was indicated by the total mass of limestone 
(in t) installed during the elapsed years in service. The mass of limestone for diversion wells was estimated as $30 \mathrm{t}$ per well for each year in service (each system had a pair of wells). In addition to acid load removed, the $\mathrm{CaCO}_{3}$ load added was computed as 2.5 times the difference in dissolved calcium load from upstream to downstream. The cost efficiency was estimated to indicate the approximate cost per tonne of acid treated over an assumed service life of 20 years. Because labor and materials for construction and maintenance of most of the treatment systems were donated or subsidized, the total cost for each treatment system was crudely estimated on the basis of the funds provided, equipment used, and the quantity of limestone and associated devices installed for treatment.

\section{Results}

Characterization of AMD Sources and Effects on Streamwater Quality

Although more than 40 AMD sources in the upper Swatara Creek Basin had been identified during previous investigations, most were minor sources of contaminant loads (Growitz et al. 1985). The major AMD sources studied during the previous and current investigations had high contaminant loads associated with high flow rates (medians greater than $100 \mathrm{~L} / \mathrm{min}$ ), such as the Tracy Airshaft, Rowe Tunnel, Middle Creek, Colket, Buck Mountain, and Hegins discharges, or low flow rates with elevated concentrations of dissolved metals, such as the Pantherhead, Shadle, and Orchard discharges (Fig. 3; Table 2). Depending on the AMD source, the flow rate at a given site varied by 1-3 log units during the current study; associated chemical variations were less pronounced. The larger volume AMD sources generally had the least-variable flow rates and chemistry. Although the Tracy Airshaft and Marshfield discharges were consistently net alkaline, the other large discharges were net acidic with near-neutral $\mathrm{pH}(>5)$ and elevated concentrations of dissolved $\mathrm{Fe}(>3 \mathrm{mg} / \mathrm{L})$. The smaller volume AMD sources were net acidic with low $\mathrm{pH}$ $(<4.5)$ and elevated concentrations of $\mathrm{Fe}, \mathrm{Al}, \mathrm{Ni}$, and $\mathrm{Zn}$ (Table 2). Concentrations of Mn typically were greater than or equal to $1 \mathrm{mg} / \mathrm{L}$ for all the AMD sources. Elevated concentrations of dissolved $\mathrm{Mn}$ and $\mathrm{Fe}$, independent of $\mathrm{pH}$ and DO (Fig. 3), generally indicate redox-controlled, kinetic limitations on the precipitation of oxidized compounds of these metals (e.g. Cravotta 2008a). Likewise decreased concentrations of dissolved $\mathrm{Al}$ with increased $\mathrm{pH}$ are consistent with solubility control by Al-hydroxide (e.g. Cravotta 2008a).

During the current study (1996-2007), the Shadle discharge exhibited the widest variability in water quality compared to other AMD sources in the watershed (Fig. 3). The net acidity of the Shadle discharge decreased progressively from a median value of $1100 \mathrm{mg} / \mathrm{L} \mathrm{CaCO}_{3}$ for 1996-1998 to a median value of $180 \mathrm{mg} / \mathrm{L} \mathrm{CaCO}_{3}$ for 2005-2007, while $\mathrm{pH}$ increased progressively from values of 3.1-3.2 in 1996-1998 to values of 4.9-6.2 in 20052007. Although a decrease in contaminant loads from an AMD source would be anticipated with treatment, the improved quality of the Shadle discharge over the study period did not result from treatment but instead from the rapid flooding of this underground mine following its closure around 1990. Permanent flooding of a mine can result in: (1) dissolution of accumulated pyrite oxidation products; (2) a decrease in the amount of oxygen that reaches the subsurface, with a corresponding decrease in the pyrite oxidation rate; and (3) progressive dilution of initially acidic water, potentially by alkaline groundwater. Extensive flooding of underground mines throughout the region and the gradual balancing of acidity and alkalinity can account for apparent natural improvement in AMD and surface-water quality and has been ongoing for decades, particularly in the northern, western, and southern Anthracite Coalfields (e.g. Raymond and Oh 2009; Wood 1996).

Despite evidence for natural attenuation of AMD contamination in the Swatara Creek Basin, downstream conditions generally were marginal for aquatic biota prior to the implementation of treatment systems. During 19961998, streamwater of Swatara Creek at Newtown and Ravine (Fig. 1) ranged from mildly acidic to near-neutral (net acidity -20 to $10 \mathrm{mg} / \mathrm{L} \mathrm{CaCO}_{3} ; \mathrm{pH}$ 4.5-8.0) with moderate concentrations of dissolved solids (SC 60$400 \mu \mathrm{S} / \mathrm{cm}$ ) that varied as a function of stream flow (Cravotta and Bilger 2001; Cravotta and Weitzel 2001). Higher values of $\mathrm{pH}, \mathrm{SC}$, and $\mathrm{SO}_{4}$ were associated with base-flow conditions sustained by near-neutral groundwater and net-alkaline AMD in the upper part of the watershed, such as the Tracy Airshaft and Colket discharges (Fig. 3). Lower values of $\mathrm{pH}, \mathrm{SC}$, and $\mathrm{SO}_{4}$ were associated with acidic storm runoff (Cravotta et al. 2010).

In contrast with Swatara Creek at Newtown and Ravine, the $\mathrm{pH}$ and SC for the headwaters of Lorberry Creek, below the Rowe Drainage Tunnel (Fig. 1), were inversely correlated with each other and varied widely (Cravotta and Weitzel 2001). Instead of storm runoff as the primary cause of variations, periodically pumped AMD with low $\mathrm{pH}$ and elevated concentrations of $\mathrm{SO}_{4}$ and other dissolved ions caused increased flows, decreased $\mathrm{pH}$, and increased SC of Lorberry Creek. Although the Rowe Drainage Tunnel drained an abandoned mine complex, an underground mine that was active below the complex during the study regularly pumped acidic water to the overlying mine pool. When the pumping was active, net acidity of Lorberry 

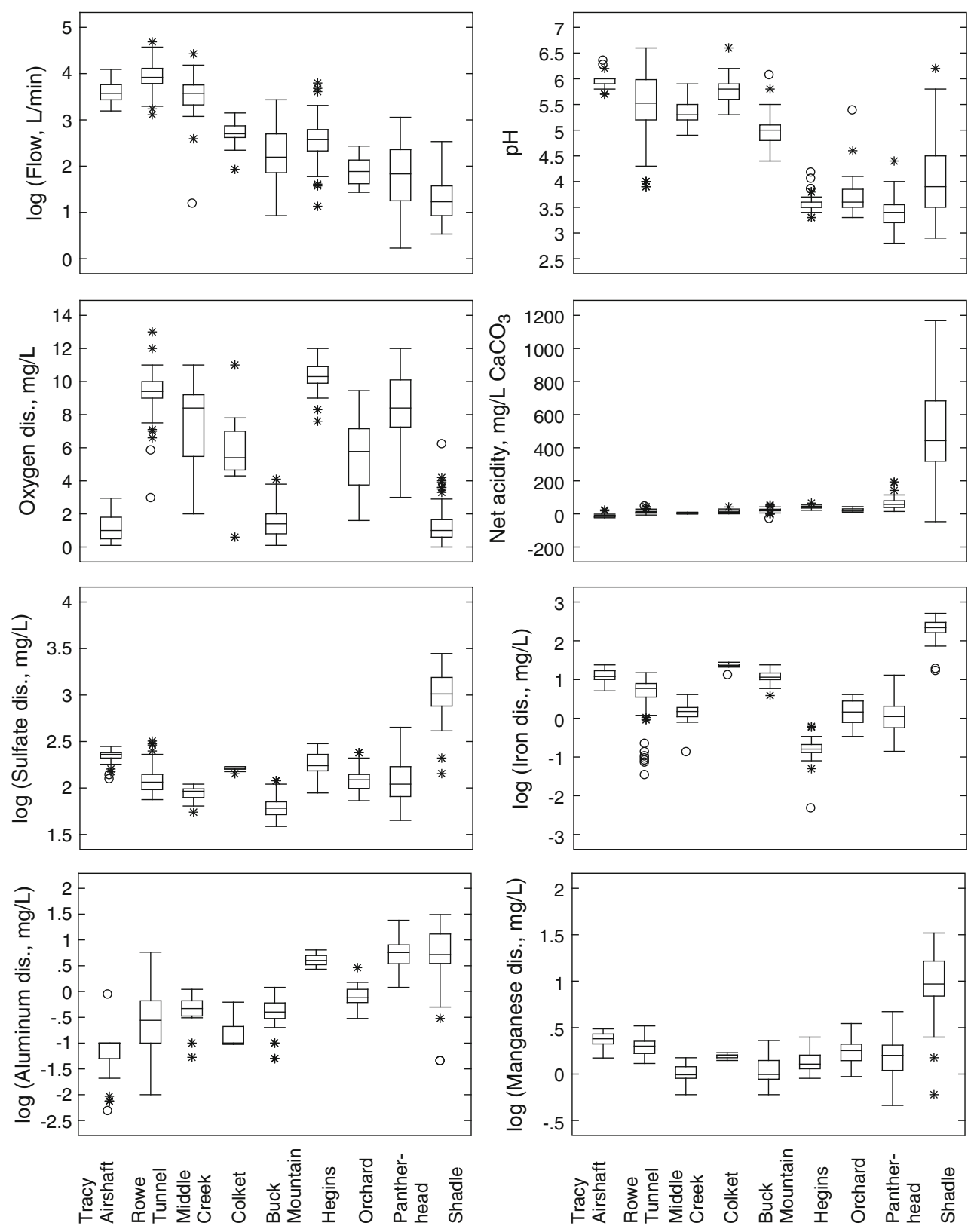

Fig. 3 Boxplots summarizing hydrochemical characteristics of AMD sources upstream from any treatment in the Swatara Creek Basin, $\mathrm{Pa}$, 1996-2007. Area of box indicates the interquartile range (IQR $=25$ th to 75th percentile); horizontal line inside the box indicates the

median; vertical lines extend to extreme values within 1.5 times the $\mathrm{IQR} ; *$ and o symbols indicate outlier values that are greater than 1.5 but less than 3 times the IQR outside the quartile, and greater than three times the IQR outside the quartile, respectively

Creek increased by $10-20 \mathrm{mg} / \mathrm{L} \mathrm{CaCO}_{3}$, $\mathrm{pH}$ declined by $0.5-1$ unit, and $\mathrm{SC}$ increased by $50-200 \mu \mathrm{S} / \mathrm{cm}$. These short-term fluctuations in $\mathrm{pH}$ and $\mathrm{SC}$ were apparent in the continuous monitoring data for Lorberry Creek at Mollystown and for Swatara Creek at Ravine, particularly during base-flow conditions (Cravotta and Weitzel 2001). Because multiple AMD sources and acidic storm runoff were possible causes of impairment of Lorberry Creek, treatment systems were implemented along stream reaches

downstream from the AMD where access and space were not limiting (Fig. 1; Table 1).

Evaluation of Treatment Performance

Generally, all eight of the treatment systems evaluated removed acidity, as indicated by significant downstream decreases (matched pair tests) in the net acidity concentration and load (Figs. 4, 5, 6). However, the median acid 
Table 2 Median water quality and constituent loading for AMD in upper Swatara Creek Basin, 1996-2007

\begin{tabular}{|c|c|c|c|c|c|c|c|c|c|c|}
\hline \multirow[t]{2}{*}{ Constituent } & \multicolumn{10}{|c|}{ AMD sites } \\
\hline & $\begin{array}{l}\text { Tracy } \\
\text { airshaft }\end{array}$ & $\begin{array}{l}\text { Rowe } \\
\text { tunnel }\end{array}$ & $\begin{array}{l}\text { Middle } \\
\text { Creek }\end{array}$ & $\begin{array}{l}\text { Marsh- } \\
\text { field }^{\mathrm{a}}\end{array}$ & Colket & $\begin{array}{l}\text { Buck } \\
\text { Mtn }\end{array}$ & Hegins & Orchard & $\begin{array}{l}\text { Panther- } \\
\text { head }\end{array}$ & Shadle \\
\hline No of observations & 31 & 134 & 19 & 1 & 17 & 45 & 54 & 20 & 60 & 72 \\
\hline Flow rate $(\mathrm{L} / \mathrm{min})$ & 3740 & 8310 & 3740 & 1400 & 501 & 132 & 374 & 77 & 51 & 17 \\
\hline Temperature $\left({ }^{\circ} \mathrm{C}\right)$ & 11 & 12 & 11 & 9.32 & 11.5 & 10.2 & 10 & 10.8 & 9.7 & 12.8 \\
\hline $\mathrm{SC}(\mu \mathrm{S} / \mathrm{cm})$ & 91 & 301 & 256 & 361 & 419 & 206 & 431 & 333 & 343 & 1730 \\
\hline DO (mg/L) & 1.0 & 9.4 & 8.4 & 3.6 & 5.4 & 1.4 & 10.3 & 5.8 & 8.4 & 1.0 \\
\hline $\mathrm{pH}$ & 5.9 & 5.5 & 5.3 & 6.4 & 5.8 & 5.0 & 3.5 & 3.6 & 3.4 & 3.9 \\
\hline $\begin{array}{l}\text { Net acidity } \\
\qquad\left(\mathrm{mg} \mathrm{CaCO}_{3} / \mathrm{L}\right)\end{array}$ & -15.5 & 9.3 & 4.6 & -59 & 12.5 & 21.9 & 38.7 & 21.5 & 57.5 & 443 \\
\hline $\begin{array}{l}\text { Alkalinity } \\
\qquad\left(\mathrm{mg} \mathrm{CaCO}_{3} / \mathrm{L}\right)\end{array}$ & 43 & 4 & 3 & 74 & 30 & 4 & 0 & 0 & 0 & 0 \\
\hline $\mathrm{SO}_{4}$, dis. $(\mathrm{mg} / \mathrm{L})$ & 230 & 115 & 92.3 & 120 & 160 & 60.6 & 174 & 123 & 110 & 1030 \\
\hline $\mathrm{Ca}$, dis. (mg/L) & 40 & 13 & 12.3 & 37 & 29 & 3.8 & 7.8 & 16.8 & 8.3 & 160 \\
\hline $\mathrm{Fe}$, dis. $(\mathrm{mg} / \mathrm{L})$ & 12 & 5.89 & 1.5 & 6.4 & 23 & 11.5 & 0.16 & 1.46 & 1.11 & 219 \\
\hline $\mathrm{Al}$, dis. $(\mathrm{mg} / \mathrm{L})$ & $<0.10$ & 0.28 & 0.467 & $<0.10$ & $<0.10$ & 0.40 & 4.0 & 0.76 & 5.7 & 5.2 \\
\hline $\mathrm{Mn}$, dis. (mg/L) & 2.4 & 2.0 & 1.0 & 1.7 & 1.6 & 1.0 & 1.3 & 1.8 & 1.6 & 9.3 \\
\hline $\mathrm{Ni}$, dis. (mg/L) & 0.055 & 0.075 & 0.053 & 0.025 & 0.061 & 0.070 & 0.111 & 0.084 & 0.140 & 0.122 \\
\hline $\mathrm{Zn}$, dis. (mg/L) & 0.038 & 0.175 & 0.130 & 0.012 & 0.064 & 0.132 & 0.295 & 0.150 & 0.375 & 0.344 \\
\hline $\begin{array}{l}\text { Net acidity } \\
\quad\left(\mathrm{kg} \mathrm{CaCO}_{3} / \mathrm{d}\right)\end{array}$ & -91 & 110 & 24 & -103 & 10 & 4 & 22 & 2 & 6 & 9 \\
\hline $\mathrm{SO}_{4}$, dis. $(\mathrm{kg} / \mathrm{d})$ & 1120 & 1550 & 470 & 222 & 121 & 12 & 90 & 12 & 11 & 15 \\
\hline $\mathrm{Ca}$, dis. $(\mathrm{kg} / \mathrm{d})$ & 217.0 & 166.0 & 69.9 & 62.3 & 23.3 & 1.0 & 4.1 & 1.6 & 0.8 & 3.8 \\
\hline $\mathrm{Fe}$, dis. $(\mathrm{kg} / \mathrm{d})$ & 88.1 & 65.5 & 9.4 & 7.2 & 19.2 & 2.4 & 0.1 & 0.2 & 0.1 & 4.9 \\
\hline $\mathrm{Al}$, dis. $(\mathrm{kg} / \mathrm{d})$ & 0.44 & 4.06 & 2.42 & 0.20 & 0.12 & 0.09 & 2.04 & 0.06 & 0.59 & 0.10 \\
\hline Mn, dis. $(\mathrm{kg} / \mathrm{d})$ & 13.2 & 24.0 & 5.3 & 2.9 & 1.2 & 0.2 & 0.7 & 0.2 & 0.1 & 0.2 \\
\hline $\mathrm{Ni}$, dis. $(\mathrm{kg} / \mathrm{d})$ & 0.281 & 0.965 & 0.227 & 0.050 & 0.052 & 0.014 & 0.065 & 0.006 & 0.015 & 0.002 \\
\hline $\mathrm{Zn}$, dis. $(\mathrm{kg} / \mathrm{d})$ & 0.160 & 2.23 & 0.599 & 0.020 & 0.025 & 0.028 & 0.175 & 0.014 & 0.039 & 0.005 \\
\hline
\end{tabular}

${ }^{a}$ Only one water-quality sample with flow data was available for the Marshfield discharge before a wetland constructed in 2000 flooded the site, preventing access

load removed (Table 3) and the magnitude of effects, if any, on the flow rate and other water-quality constituents varied widely among the treatment systems. Although upstream and downstream time-series data for flow rates and a variety of water-quality constituents were evaluated and are accessible in an electronic appendix net-acidity data are emphasized in the following evaluations of the treatment performance.

For example, as implied by decreased acidity, the limestone drains at the Hegins and Buck Mountain discharges $(\mathrm{ODH}, \mathrm{ADB})$ and the limestone diversion wells on Swatara Creek and Lorberry Creek (DWS, DWL) increased the $\mathrm{pH}$ and decreased the dissolved $\mathrm{Fe}$ and $\mathrm{Al}$ loads downstream. However, the limestone sand on Coal Run (LSC) and the open limestone channel on Swatara Creek (OLS) had only minor effects, if any, on the $\mathrm{pH}$ and dissolved metals loads (Fig. 6). Likewise, the two wetland systems along Lorberry Creek and Lower Rausch Creek
(WLL, WLR) decreased dissolved Fe and Al loads but had varying effects on $\mathrm{pH}$. The results of treatment by individual systems and factors affecting their performance are described below.

\section{Limestone-Sand Dosing on Coal Run (LSC; C4-C6)}

The limestone-sand dosing at Coal Run was aptly called dumping, whereby several truckloads of finely crushed limestone were spilled at once over the stream bank into the channel. As the mound of limestone sand was eroded at the base, fresh limestone spilled into the channel where it gradually dissolved. Stream flow in the treated section of Coal Run ranged from 8.5 to $215 \mathrm{~L} / \mathrm{s}$, and originated as AMD from several sources similar in quality to the Middle Creek and Marshfield discharges (Fig. 3; Table 2). The stream water above (C4) and below (C6) the treated reach had similar flow and water quality, characterized by net 

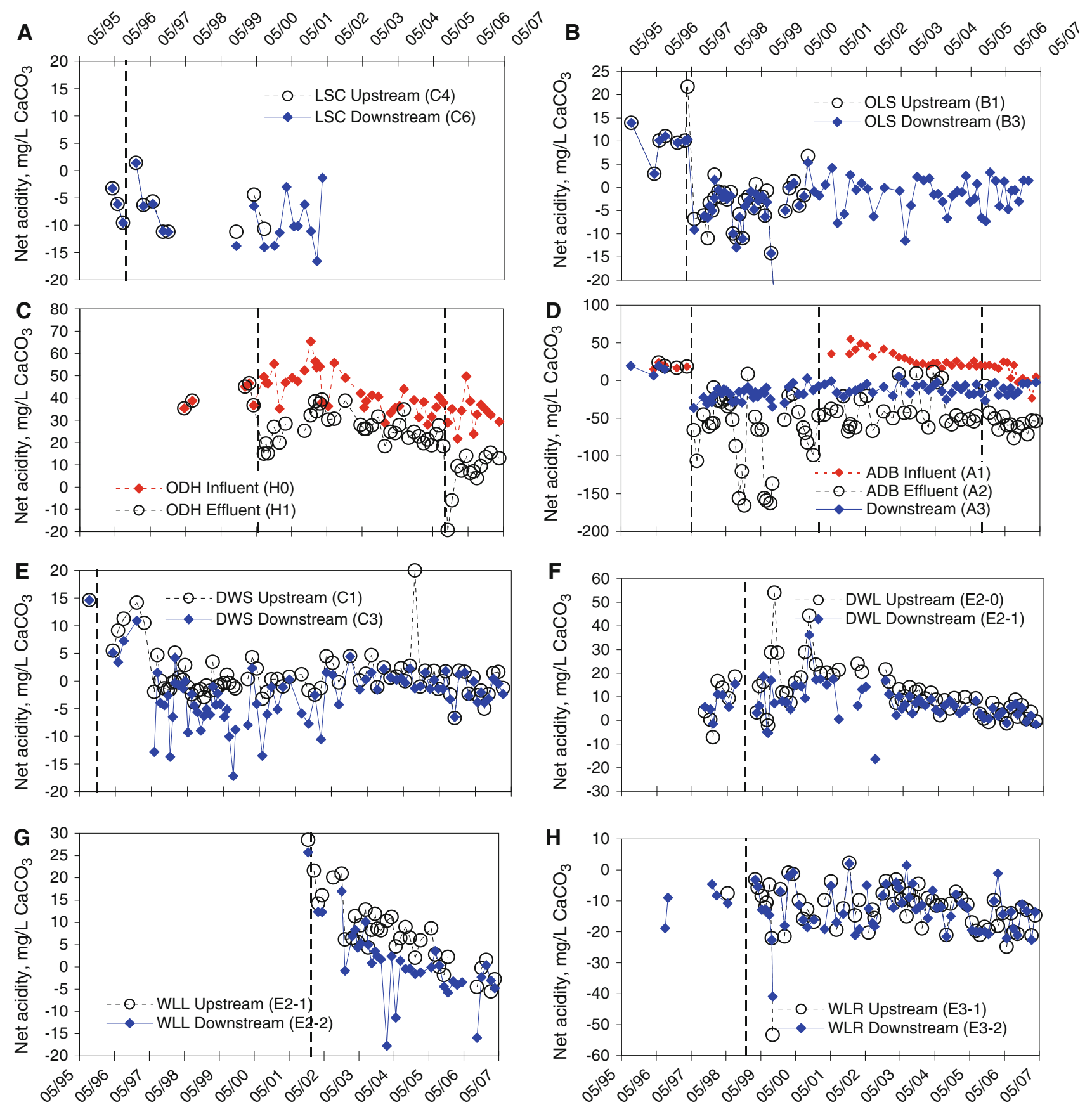

Fig. 4 Net acidity concentrations upstream and downstream of selected treatment systems in the Swatara Creek Basin; vertical dashed lines indicate when treatment started or supplemental addition of limestone: a limestone sand in Coal Run (LSC); b open limestone channel on Swatara Creek (OLS); c oxic limestone drain at Hegins

discharge (ODH); d anoxic limestone drain at Buck Mountain discharge (ADB); e limestone diversion wells on Swatara Creek (DWS); f limestone diversion wells on Lorberry Creek (DWL); $\mathbf{g}$ aerobic wetlands on Lorberry Creek (WLL); h aerobic limestonecompost wetlands on Lower Rausch Creek (WLR)

acidity concentrations from 11.2 to $1.4 \mathrm{mg} / \mathrm{L} \mathrm{CaCO}_{3}$ (Fig. 4a), $\mathrm{pH}$ values from 5.6 to 6.9 , and moderate concentrations of dissolved metals (Fe $0.5-2.0 \mathrm{mg} / \mathrm{L} ; \mathrm{Mn}$ $0.76-1.2 \mathrm{mg} / \mathrm{L} ; \mathrm{Al}<0.5 \mathrm{mg} / \mathrm{L}$ ) (Supplementary material). Although the matched-pair tests indicated the downstream concentrations and loads of net acidity decreased and of

dissolved $\mathrm{Ca}$ and $\mathrm{Mn}$ increased (Fig. 6), the $\mathrm{pH}$ and dissolved concentrations and loads of $\mathrm{Fe}$ and $\mathrm{Al}$ were not significantly different between the upstream and downstream sites for most conditions. Increased Mn was not expected, but could be an impurity in the limestone. The limestone-sand treatment on Coal Run removed a median 

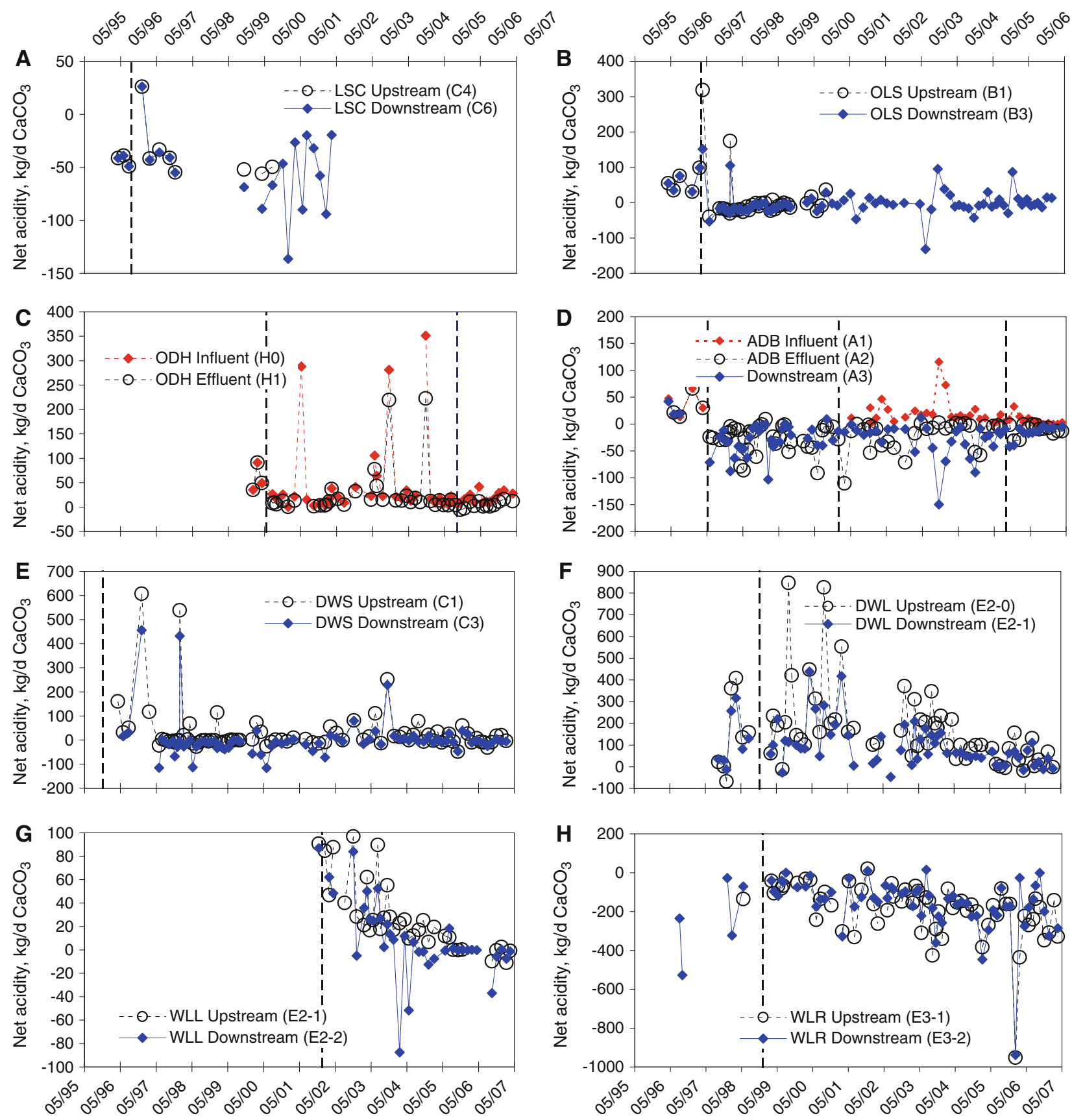

Fig. 5 Net acidity loads upstream and downstream of selected treatment systems in the Swatara Creek Basin; vertical dashed lines indicate when treatment started or supplemental addition of limestone: a limestone sand in Coal Run (LSC); b open limestone channel on Swatara Creek (OLS); c oxic limestone drain at Hegins discharge

(ODH); $\mathbf{d}$ anoxic limestone drain at Buck Mountain discharge (ADB); e limestone diversion wells on Swatara Creek (DWS); f limestone diversion wells on Lorberry Creek (DWL); $\mathbf{g}$ aerobic wetlands on Lorberry Creek (WLL); $\mathbf{h}$ aerobic limestone-compost wetlands on Lower Rausch Creek (WLR)

acidity of 1.9 t/year and added $2.2 \mathrm{t} /$ year $\mathrm{Ca}$ as $\mathrm{CaCO}_{3}$ over the 6-year monitoring period (Figs. 5a, 6; Table 3). Compared to the other seven treatment systems, the limestone-sand treatment of Coal Run had relatively high acid-removal efficiency $(47.5 \mathrm{~g} / \mathrm{d} / \mathrm{t})$ and the best estimated cost efficiency (\$108/t) (Table 3).

\section{Open Limestone Channel on Swatara}

Creek (OLS; B1-B3)

Before implementing treatment in March 1997, the stream water at sites $\mathrm{B} 1$ and $\mathrm{B} 3$ was acidic $\left(3-14 \mathrm{mg} / \mathrm{L} \mathrm{CaCO}_{3}\right)$ (Fig. 4b), with low $\mathrm{pH}(<4.5)$, low concentrations of $\mathrm{SO}_{4}$ 

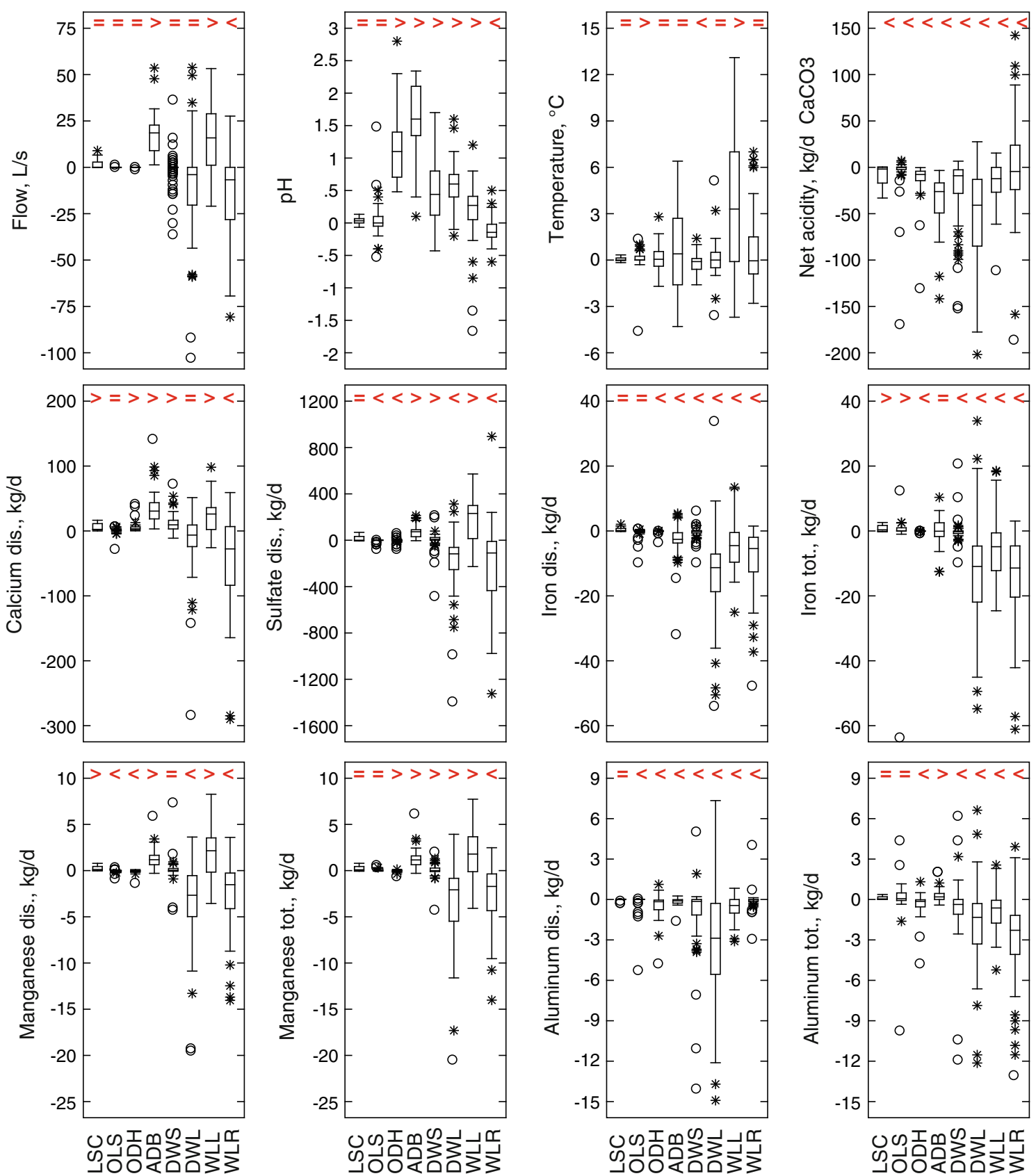

Fig. 6 Boxplots of post-implementation data showing differences in water quality between downstream and upstream sites for selected treatment systems in the Swatara Creek Basin. Axis labels are: LSC, limestone sand in Coal Run (C6-C4); OLS, open limestone channel on Swatara Creek (B3-B1); ODH, oxic limestone drain at Hegins discharge (H1-H0); ADB, anoxic limestone drain at Buck Mountain discharge (A3-A1); DWS, limestone diversion wells on Swatara Creek (C3-C1); DWL, limestone diversion wells on Lorberry Creek

$(12-48 \mathrm{mg} / \mathrm{L})$ and $\mathrm{Mn}(<0.5 \mathrm{mg} / \mathrm{L})$, and moderate concentrations of dissolved $\mathrm{Al}$ and $\mathrm{Fe}(0.5-3 \mathrm{mg} / \mathrm{L}$ ) (Supplementary material). These conditions and preliminary field experiments indicating initially rapid increases in the $\mathrm{pH}$ and minor decreases in acidity of stream water in

(E2-1-E2-0); WLL, aerobic wetlands on Lorberry Creek (E2-2-E21); WLR, aerobic limestone-compost wetlands on Lower Rausch Creek (E3-2-E3-1). See explanation of boxplot symbols in Fig. 3. Symbols at the top of each boxplot indicate if the mean rank at downstream site was equal to $(=)$, greater than $(>)$, or less than $(<)$ that for the upstream site on the basis of the Wilcoxon matched-pair signed-rank test (Helsel and Hirsch 2002)

contact with limestone in an 'open container' warranted the construction of the open limestone channel. The preliminary experiments indicated the rates of limestone dissolution and acid neutralization decreased with increased $\mathrm{pH}$, which is consistent with open container 
Table 3 Characteristics of treatment systems in the upper Swatara Creek Basin, including flow (L/s), median influent (Infl) and effluent (Effl) quality, acid load removed or $\mathrm{CaCO}_{3}$ load added (t/year), size as mass (t) or area $\left(\mathrm{m}^{2}\right)$, years in service, estimated costs (US\$), removal efficiency (R.E.) $(\mathrm{g} / \mathrm{d} / \mathrm{t})$ or $\left(\mathrm{g} / \mathrm{d} / \mathrm{m}^{2}\right)^{\mathrm{ab}}$, and cost efficiency (C.E.) $(\$ / t)^{c}$ for

\begin{tabular}{|c|c|c|c|c|c|c|c|c|c|c|c|c|c|}
\hline & \multirow{2}{*}{$\begin{array}{l}\text { No of } \\
\text { sample } \\
\text { pairs }\end{array}$} & \multirow[t]{2}{*}{ Flow } & \multicolumn{2}{|l|}{$\mathrm{pH}$} & \multicolumn{2}{|c|}{ Net acidity $(\mathrm{mg} / \mathrm{L})$} & \multirow{2}{*}{$\begin{array}{l}\text { Acid load } \\
\text { removed }\end{array}$} & \multirow{2}{*}{$\begin{array}{l}\mathrm{CaCO} 3 \text { load } \\
\text { added }\end{array}$} & \multirow[t]{2}{*}{ Size $^{\mathrm{d}}$} & \multirow{2}{*}{$\begin{array}{l}\text { Years in } \\
\text { service }\end{array}$} & \multirow[t]{2}{*}{$\operatorname{Cost}^{\mathrm{e}}$} & \multirow[t]{2}{*}{ R.E. } & \multirow[t]{2}{*}{ C.E. } \\
\hline & & & Infl & Effl & Infl & Effl & & & & & & & \\
\hline LSC & 11 & 56.6 & 6.5 & 6.5 & -8.5 & -8.8 & -1.9 & 2.2 & $40 \mathrm{t}$ & 11 & 1,500 & 47.5 & 108 \\
\hline OLS & 39 & 62.3 & 6.4 & 6.5 & -2.8 & -3.0 & -0.2 & 0.1 & $100 \mathrm{t}$ & 10 & 3,500 & 2.0 & 2,397 \\
\hline $\mathrm{ODH}$ & 50 & 5.4 & 3.5 & 4.6 & 38.2 & 23.2 & -7.7 & 3.0 & $909 \mathrm{t}$ & 7 & 50,000 & 8.5 & 891 \\
\hline $\mathrm{ADB}$ & 38 & 24.6 & 5.0 & 6.6 & 23.2 & -10.1 & -26.2 & 27.9 & $502 \mathrm{t}$ & 10 & 25,000 & 52.1 & 131 \\
\hline DWS & 82 & 82.4 & 5.5 & 6.0 & 0.0 & -1.6 & -9.1 & 8.6 & $840 \mathrm{t}$ & 12 & 68,800 & 12.7 & 1,035 \\
\hline DWL & 64 & 131.7 & 5.5 & 6.2 & 9.3 & 6.2 & -40.9 & 1.3 & $630 \mathrm{t}$ & 9 & 68,800 & 75.8 & 230 \\
\hline WLL & 33 & 56.1 & 5.7 & 6.0 & 6.5 & 0.6 & -12.3 & 23.8 & $4,860 \mathrm{~m}^{2}$ & 6 & 142,000 & 2.5 & 1,584 \\
\hline WLR & 61 & 157.5 & 7.0 & 6.8 & -11.5 & -12.9 & -3.1 & -27.0 & $9,310 \mathrm{~m}^{2}$ & 9 & 175,000 & 0.3 & 7,783 \\
\hline
\end{tabular}

${ }^{a}$ R.E. computed as acid load removed divided by area of wetland, multiplied by conversion factor of 1,000 g/kg

${ }^{b}$ R.E. for limestone-based systems expressed as g of acidity as $\mathrm{CaCO}_{3}$ removed per day per $\mathrm{t}$ of limestone; for wetlands, computed as acid load removed divided by area of wetland, multiplied by conversion factor of $1,000 \mathrm{~g} / \mathrm{kg}$

${ }^{c}$ C.E. expressed as $\$ / \mathrm{t}$ of acidity as $\mathrm{CaCO}_{3}$ removed, assuming a 20 year service life, multiplied by a conversion factor of $2.74(\mathrm{~d} \cdot \mathrm{t}) /(\mathrm{year} \mathrm{kg})$

${ }^{\mathrm{d}}$ Size of limestone-based system in tonnes of limestone; size of wetland in $\mathrm{m}^{2}$

e The cost to build and maintain the diversion wells was estimated, assuming $\$ 20,000$ for initial well installation with hopper storage, $\$ 24 / t$ for limestone over 20 years, and $\$ 1,000$ a year for operation and maintenance (filling wells, clearing debris from intakes)

testing of nearby AMD (e.g. Cravotta 2003; Cravotta et al. 2004).

The first pair of post-implementation samples collected in April 1997 indicated net acidity decreased by $11 \mathrm{mg} / \mathrm{L}$ $\mathrm{CaCO}_{3}$ or $50 \%$ (Figs. 4b, 5b) and $\mathrm{pH}$ increased by 0.5 unit (Supplementary material). However, water quality benefits were not as pronounced after May 1997, following the installation of an anoxic limestone drain on the Buck Mountain discharge at site A2 that produced near-neutral stream water at site B1 above the open limestone channel. The neutral upstream water was not aggressive toward limestone in the stream channel compared to the initially acidic stream water. Nevertheless, the concentrations and loads of net acidity and dissolved $\mathrm{SO}_{4}, \mathrm{Al}$, and $\mathrm{Mn}$ exhibited significant decreases between the upstream site (B1) and downstream site (B3) at the open limestone channel (Fig. 6). Overall differences in $\mathrm{pH}$ and concentrations of dissolved $\mathrm{Ca}$ and $\mathrm{Fe}$ were not significant for any flow conditions (Fig. 6). The limestone channel treatment on Swatara Creek removed a median acidity of $0.2 \mathrm{t} /$ year and added $0.1 \mathrm{t}$ /year $\mathrm{Ca}$ as $\mathrm{CaCO}_{3}$ over a 4-year monitoring period with paired samples (Fig. 6; Table 3). Compared to the other seven treatments, the limestone channel on Swatara Creek had the lowest acid-removal efficiency $(2.0 \mathrm{~g} / \mathrm{d} / \mathrm{t})$ and the worst estimated cost efficiency $(\$ 2,397 /$ t) (Table 3). Considering initial results when the influent stream water was acidic, the efficiency may be expected to decrease as the influent quality improves.
Oxic Limestone Drain on Hegins Discharge $(\mathrm{ODH} ; \mathrm{HO}-\mathrm{HI})$

Before implementing treatment in June 2000, untreated AMD flowed from the Hegins discharge at site $\mathrm{HO}$ for about $100 \mathrm{~m}$ as an unnamed tributary to site $\mathrm{H} 1$ at Swatara Creek (Fig. 1). The oxic limestone drain was constructed as a series of limestone-filled cells within the channel of this unnamed tributary. The untreated AMD was oxic (DO 7.6-12 mg/L) and acidic (net acidity 22$65 \mathrm{mg} / \mathrm{L})$ with low $\mathrm{pH}(3.3-4.2)$ and elevated concentrations of dissolved $\mathrm{Al}(2.7-6.4 \mathrm{mg} / \mathrm{L})$ and $\mathrm{Mn}(0.9$ $2.5 \mathrm{mg} / \mathrm{L})$ but moderate concentrations of dissolved $\mathrm{Fe}$ $(<1 \mathrm{mg} / \mathrm{L}$ ) (Fig. 3). Compared to the influent, the treated effluent had lower concentrations of net acidity (Fig. 4c), higher $\mathrm{pH}$ (4.0-6.9; median increase of 1.1), and lower concentrations of dissolved metals (Supplementary material). After the system was enlarged with additional limestone and covered with compost in September 2005, the treatment effectiveness improved (Fig. $4 \mathrm{c}$ and Supplementary material). Over the 7 year monitoring period, the oxic limestone drain on the Hegins discharge removed a median acidity of $7.7 \mathrm{t} /$ year and added 3.0 t/year $\mathrm{Ca}$ as $\mathrm{CaCO}_{3}$ (Table 3). Compared to the other seven treatment systems, the oxic limestone drain treatment had relatively low acid-removal efficiency $(8.5 \mathrm{~g} / \mathrm{d} / \mathrm{t})$ and moderately high estimated cost $(\$ 891 / \mathrm{t})$ (Table 3). 
Anoxic Limestone Drain on Buck Mountain Discharge (ADB;A1-A3)

Before implementing treatment in May 1997, untreated AMD flowed from the Buck Mountain discharge at site A1 for about $550 \mathrm{~m}$ as an unnamed tributary to site A3 near the headwaters of Swatara Creek (Fig. 1). The untreated AMD generally was suboxic (DO $<2.0 \mathrm{mg} / \mathrm{L}$ ) with slightly acidic $\mathrm{pH}$ (4.1-6.1) and elevated concentrations of dissolved Fe (4-24 mg/L) but moderate concentrations of dissolved $\mathrm{Al}(\leq 1.2 \mathrm{mg} / \mathrm{L})$ and $\mathrm{Mn}$ ( $\leq 2.3 \mathrm{mg} / \mathrm{L})$ (Fig. 3). As this untreated effluent flowed downstream to site A3, the $\mathrm{pH}$ and concentrations of dissolved Fe decreased due to oxidation and hydrolysis reactions; however, dissolved $\mathrm{Al}$ remained elevated ( $>0.3 \mathrm{mg} / \mathrm{L}$ ) (Supplementary material).

After implementation of the ALD, the downstream water at site A3 had positive net alkalinity (net acidity $<0$ ) (Fig. 4d) and consistently near-neutral pH (Supplementary material). In addition to the decreased acidity concentrations and loads (Figs. 4d, 5d), the effluent from the ALD at site A2 had significantly higher $\mathrm{pH}$ (median increase 1.6), greater concentrations and loads of $\mathrm{Ca}$, and smaller concentrations and loads of dissolved $\mathrm{Fe}$ and $\mathrm{Al}$ than the influent at A1 (Fig. 6). These effluent characteristics were consistent with results of closed-container tests with the AMD from the Buck Mountain discharge (Cravotta 2003; Cravotta et al. 2004). In contrast with pretreatment conditions, the $\mathrm{pH}$ of treated effluent increased downstream to site $\mathrm{A} 3$ due to the exsolution of $\mathrm{CO}_{2}$ (Supplementary material). Because of additional inflows of diffuse AMD along the tributary, the flow rate, net acidity, and $\mathrm{SO}_{4}$ concentrations also increased downstream. Nevertheless, alkalinity added by the ALD was sufficient to buffer the downstream $\mathrm{pH}$ at site A3.

The ALD decreased the acidity by a median of 26.2 t/year and increased dissolved $\mathrm{Ca}$ by a median of 27.9 t/year as $\mathrm{CaCO}_{3}$ (Table 3). This added $\mathrm{CaCO}_{3}$ load was substantially larger than that from other limestone treatment systems in the watershed and indicates a rapid rate of limestone dissolution in the ALD, as explained in detail by Cravotta (2003) and Cravotta et al. (2004). Because of the rapid rate of limestone consumption, the Buck Mountain ALD, which had an original size of $320 \mathrm{t}$, was enlarged during the study with the addition of $100 \mathrm{t}$ of limestone in January 2001 and again in September 2005. Including these enlargements, the ALD treatment had relatively high acidremoval efficiency $(52.1 \mathrm{~g} / \mathrm{d} / \mathrm{t})$ and a low estimated cost $(\$ 131 / \mathrm{t})$ compared to the other treatment systems (Table 3).

The ALD was effective for neutralization of AMD and attenuation of dissolved metals over the range of flow conditions but was not always effective for attenuation of total metals. Specifically, during low-flow conditions, the concentration of total $\mathrm{Al}$ decreased downstream from site A1 to site A3 (Supplementary material). However, sporadically during normal to high-flow conditions, the concentration and load of total Al increased downstream (Supplementary material). During normal to high flows, turbulent water could transport freshly precipitated Al-hydroxide particles downstream.

\section{Limestone Diversion Wells on Swatara Creek} (DWS; $C 1-C 3$ )

Before implementing treatment in July 1997, the stream water at sites $\mathrm{C} 1$ and $\mathrm{C} 3$ had the same acidity (Fig. 4e), $\mathrm{pH}<4.5$, dissolved $\mathrm{Al}>1.5 \mathrm{mg} / \mathrm{L}$, and associated constituents (Supplementary material). After implementation of the treatment, the stream water at the downstream site (C3), approximately $140 \mathrm{~m}$ below the diversion wells, typically had a concentration of acidity that was $2 \mathrm{mg} / \mathrm{L}$ $\mathrm{CaCO}_{3}$ lower and a $\mathrm{pH}$ that was 0.5 unit higher than the upstream site (C1) (Fig. 6 and Supplementary material). The median decrease in net acidity load was $9.1 \mathrm{t} / \mathrm{year}$, and the increase in $\mathrm{Ca}$ load was $8.6 \mathrm{t} /$ year as $\mathrm{CaCO}_{3}$. Assuming limestone consumption at a rate of $30 \mathrm{t} / \mathrm{year}$ for each diversion well, the treatment on Swatara Creek had relatively low acid-removal efficiency $(12.7 \mathrm{~g} / \mathrm{d} / \mathrm{t})$ and high estimated cost $(\$ 1,035 / \mathrm{t})$ compared to the other treatment systems (Table 3 ).

For most flow conditions, the limestone diversion wells decreased concentrations of net acidity, increased $\mathrm{pH}$ and concentrations of $\mathrm{Ca}$, and decreased dissolved $\mathrm{Fe}$ and $\mathrm{Al}$ (Fig. 6 and Supplementary material). Nevertheless, during extreme high-flow conditions associated with tropical storms in September 1999 and spring storms in MarchMay 2000, the pH of downstream water (continuously monitored) was not effectively increased (Cravotta and Weitzel 2001). During such extreme storm flow conditions, the effectiveness of the limestone diversion wells was diminished because a smaller proportion of total stream flow was treated.

\section{Limestone Diversion Wells on Lorberry Creek (DWL;E2-0-E2-1)}

Lorberry Creek at site E2-0 consisted predominantly of effluent from the Rowe Drainage Tunnel, which had extremely variable net acidity -2.2 to $54 \mathrm{mg} / \mathrm{L}$ as $\mathrm{CaCO}_{3}$ ) and $\mathrm{pH}(3.9-6.5)$ and elevated concentrations of dissolved Fe (2.0-12 mg/L) and Al (0.01-5.8 mg/L) (Figs. 3, 4f). Although the diversion wells on Lorberry Creek below Rowe Drainage Tunnel did not treat the entire flow of the Rowe Tunnel, they effectively decreased net acidity, increased $\mathrm{pH}$, and decreased dissolved $\mathrm{Fe}$ and $\mathrm{Al}$ concentrations in the downstream segment of Lorberry Creek at 
site E2-1 over a wide range of flow conditions (Fig. 4f and Supplementary material). The median decrease in net acidity load was 40.9 t/year, but the increase in Ca load was only $1.3 \mathrm{t} /$ year as $\mathrm{CaCO}_{3}$. Assuming limestone consumption at a rate of $30 \mathrm{t} / \mathrm{year}$ for each diversion well, the treatment on Lorberry Creek had very high acid-removal efficiency $(75.8 \mathrm{~g} / \mathrm{d} / \mathrm{t})$ and relatively low estimated cost $(\$ 230 / \mathrm{t})$ compared to the other treatment systems (Table 3). Nevertheless, the large inconsistency between the acid load removed and the $\mathrm{CaCO}_{3}$ load added (Table 3) could indicate a source of alkalinity other than the limestone diversion wells between the upstream and downstream monitoring sites, such as soda ash (sodium carbonate) from an abandoned treatment tank below the upstream monitoring site. Using the $\mathrm{CaCO}_{3}$ load added as a surrogate for the acid removal associated with the limestone diversion wells, the removal efficiency decreases to $2.4 \mathrm{~g} / \mathrm{d} / \mathrm{t}$ and the estimated cost increases to $\$ 7,377 / \mathrm{t}$, which would be among the least efficient of the treatment systems.

The limestone diversion wells on Lorberry Creek added alkalinity and increased $\mathrm{pH}$ over most flow conditions. Nevertheless, during extreme high-flow conditions associated with large storms, the $\mathrm{pH}$ changed little (Cravotta and Weitzel 2001) and the dissolved $\mathrm{Ca}$ concentration decreased downstream of the diversion wells on Lorberry Creek. During high-flow conditions, a large fraction of the AMD bypassed the diversion wells and the treated effluent could be diluted by runoff or groundwater seepage between the upstream and downstream monitoring sites.

\section{Aerobic Wetlands Below Diversion Wells on Lorberry Creek (WLL; E2-1A-E2-3)}

Before installation of the aerobic wetlands in December 2001 downstream from the diversion wells on Lorberry Creek, the effluent from the diversion wells was discharged directly to the stream where the increased $\mathrm{pH}$ from treatment promoted the precipitation of $\mathrm{Fe}$ and $\mathrm{Al}$ solids in the stream channel. The wetlands were constructed to remove the metals from the effluent by providing a location for the oxidation of $\mathrm{Fe}$ and settling of metal-rich solids.

Compared to the influent, the effluent from the wetlands downstream of the diversion wells on Lorberry Creek had lower concentrations and loads of acidity and dissolved and total $\mathrm{Fe}$ and $\mathrm{Al}$ plus higher $\mathrm{pH}$ (Figs. 4g, 6). Concentrations and loads of dissolved $\mathrm{Ca}$ and $\mathrm{Mn}$ increased within the wetlands because of continuous groundwater seepage into the wetlands and, to a lesser extent, the irregular addition of hydrated lime to the influent (a lime doser was rarely in service). The median decrease in net acidity load was $12.3 \mathrm{t} /$ year, and the increase in $\mathrm{Ca}$ load was $23.8 \mathrm{t} / \mathrm{year}$ as $\mathrm{CaCO}_{3}$. Ignoring the quantities and cost of the added lime, the wetland treatment on Lorberry Creek had very low acid-removal efficiency $(2.5 \mathrm{~g} / \mathrm{d} / \mathrm{t})$ and relatively high estimated cost $(\$ 1,584 / \mathrm{t})$ compared to the other treatment systems (Table 3). If the cost for lime was considered, the estimated treatment cost would be even greater.

Although the Lorberry wetlands effectively removed $\mathrm{Fe}$ and $\mathrm{Al}$ from Lorberry Creek, they had another unintended effect. Instead of sustaining a year-round water temperature of approximately $13^{\circ} \mathrm{C}$ exhibited by the Rowe Tunnel discharge and the Lorberry Creek diversion well effluent (Supplementary material), the temperature of the wetland effluent ranged widely (Fig. 6 and Supplementary material). During summer, the temperature of the wetland effluent increased to $25.4^{\circ} \mathrm{C}$, which greatly exceeds the upper limit of $18.7^{\circ} \mathrm{C}$ for a cold-water fishery (Commonwealth of Pennsylvania 2002). Although brook trout were reported in the lower reaches of Lorberry Creek during the study period (Cravotta et al. 2010), the potential for adverse temperature effects would need to be considered in possible plans for additional wetlands to treat other AMD sources, such as the Shadle or Pantherhead discharges (Fig. 1).

\section{Limestone-Compost-Based Wetlands on Lower Rausch Creek (WLR; E3-1-E3-2)}

The wetlands constructed in December 1997 on Lower Rausch Creek impounded stream flow within a highway fill area that was underlain by boulders and was prone to losing water. Hence, because of seepage losses and evaporative losses, the flow rate exiting the wetlands typically was less than that entering the wetlands (Fig. 6 and Supplementary material). If the decreased flow resulted solely from evaporation, the dissolved chemical concentrations could increase within the wetlands, whereas the loads of relatively conservative solutes, such as $\mathrm{SO}_{4}$, would not be affected. The upstream water entering the Rausch Creek wetlands had concentrations of net acidity of -24.8 to $2.3 \mathrm{mg} / \mathrm{L} \mathrm{CaCO}_{3}, \mathrm{pH}$ 6.2-7.8, and widely variable concentrations of dissolved $\mathrm{SO}_{4}$ of $62-207 \mathrm{mg} / \mathrm{L}$, and $\mathrm{Fe}, \mathrm{Al}$, and $\mathrm{Mn}$, ranging from $<0.05$ to $>1.5 \mathrm{mg} / \mathrm{L}$ (Supplementary material). In comparison, the water downstream from the wetlands exhibited significantly lower concentrations and loads of net acidity, dissolved $\mathrm{SO}_{4}$, and dissolved and total $\mathrm{Fe}, \mathrm{Al}$, and $\mathrm{Mn}$, plus lower pH (Figs. 4h, 5h, 6). Although the concentrations of dissolved and total $\mathrm{Ca}$ were equivalent for the influent and effluent, the load of $\mathrm{Ca}$ decreased through the wetlands (Supplementary material).

The Rausch Creek wetlands removed a median acidity load of $3.1 \mathrm{t} /$ year (Table 3). In contrast with the other treatment systems that exported $\mathrm{Ca}$, the Rausch Creek wetlands removed 27.0 t/year $\mathrm{Ca}$ as $\mathrm{CaCO}_{3}$, which resulted from flow losses through the wetlands. Compared to the 
other treatment systems, the wetland treatment on Rausch Creek had the lowest acid-removal efficiency $(0.3 \mathrm{~g} / \mathrm{d} / \mathrm{t})$ and the highest estimated cost $(\$ 7,783 / \mathrm{t})$ (Table 3). Considering that flow losses magnified the apparent acidremoval rates, the actual treatment efficiency would be worse than indicated.

Despite flow losses, chemical reactions could have caused a decrease in the concentrations and loads of dissolved $\mathrm{SO}_{4}$ and dissolved $\mathrm{Fe}, \mathrm{Al}$, and $\mathrm{Mn}$ within the Rausch Creek wetlands (Fig. 6 and Supplementary material). Negative values of the saturation index for gypsum $\left(\mathrm{CaSO}_{4} \cdot 2 \mathrm{H}_{2} \mathrm{O} ; \mathrm{SI} \leq-1.35\right)$ indicate that precipitation of $\mathrm{SO}_{4}$ from the effluent would not have been a feasible mechanism for its removal. In contrast, the effluent typically was near saturation or supersaturated with respect to $\mathrm{Fe}(\mathrm{OH})_{3}$ and $\mathrm{Al}(\mathrm{OH})_{3}$, indicating potential for removal of dissolved $\mathrm{Fe}$ and $\mathrm{Al}$ by precipitation of such phases. Although the water column was presumed aerobic, reducing conditions could have developed in the underlying compost substrate. The implication is that multiple processes such as $\mathrm{Fe}$ oxidation and settling within the water column and dissimilatory $\mathrm{SO}_{4}$ reduction within the compost substrate may have been occurring in the wetlands. Because the median $\mathrm{pH}$ decreased within the wetlands, alkalinity produced by $\mathrm{SO}_{4}$ reduction (if active) was not sufficient to buffer acidity released by any such $\mathrm{Fe}^{\mathrm{III}}$ or $\mathrm{Al}$ hydrolysis reactions. Furthermore, although most pairs of samples indicated declines in metal concentrations and transport from the upstream to downstream monitoring sites, three pairs of samples collected during stormflow conditions indicated concentrations of total metals and suspended solids were greater at the downstream site than the upstream site for the Rausch Creek wetlands. Consequently, the wetlands could export metals during high-flow conditions.

As described for the Lorberry Creek wetlands, the temperature of the Rausch Creek wetland effluent increased to $24^{\circ} \mathrm{C}$ during summer months, which exceeds the upper limit of $18.7^{\circ} \mathrm{C}$ for a cold-water fishery (Commonwealth of Pennsylvania 2002). Although seepage losses from the Rausch Creek wetland were unintended and were not monitored directly, a treatment system designed to transmit wetland effluent through the subsurface before discharging to the stream could reduce the effect of temperature variations resulting from impoundment of water within wetlands (e.g. Cravotta 2007).

\section{Discussion}

Results of monitoring during 1996-2007 of six limestone treatment systems designed for acid removal and two wetland systems designed to remove precipitated metals indicate that the ALD on the Buck Mountain discharge (treatment ADB at site A1 in Fig. 1) near the headwaters of Swatara Creek had the greatest overall benefit. This ALD, which had been in service for more than 10 years, consistently exported an annual load of $\mathrm{CaCO}_{3}$ greater than $26 \mathrm{t} /$ year, equivalent to the acid removed, and produced significant improvement in $\mathrm{pH}$ of downstream water for relatively low estimated cost. Compared to the 29 ALDs evaluated by Ziemkiewicz et al. (2003), the median flow rate treated by the Buck Mountain ALD was two times greater than the highest they reported, and the acid-removal efficiency was near the median value for other ALDs. However, the estimated cost for the Buck Mountain ALD was greater than $75 \%$ of the ALDs evaluated by Ziemkiewicz et al. (2003), reflecting added expenses incurred for enlarging the Buck Mountain treatment system in 2001 and 2005.

The other treatment systems in the upper Swatara Creek Basin had treatment efficiencies and estimated cost efficiencies within the ranges reported by Ziemkiewicz et al. (2003). The limestone-sand treatment on Coal Run (LSC) was relatively effective and the least expensive for acid removal. The open limestone channel on Swatara Creek (OLS) was among the most expensive per ton of acid removed. The oxic limestone drain on the Hegins discharge (ODH) and the limestone diversion wells on Swatara Creek (DWS) and Lorberry Creek (DWL) were intermediate in treatment and estimated cost efficiency.

On average, the diversion wells on Lorberry Creek and Swatara Creek treated a larger flow volume than the other treatment systems. The diversion wells were effective in removing acidity and increasing $\mathrm{pH}$ of downstream water and exhibited unique potential to treat rapidly changing, moderate to high flows. Because storm flow generally was more acidic than base flow in the Swatara Creek, diversion wells could be useful to augment treatments by other limestone-based systems at upstream or downstream sites. However, diversion-well systems are relatively expensive to operate because they require routine maintenance to ensure that they contain sufficient limestone through the duration of a treatment event and that they do not become clogged with debris. Although a large fraction of the stream flow bypassed the diversion wells on Swatara Creek and Lorberry Creek during the highest flow conditions, multiple diversion wells with intakes at higher elevations than normal base-flow stage could be added to treat progressively larger volumes during such storm flow events.

At near-neutral $\mathrm{pH}$, the transport of dissolved $\mathrm{Fe}, \mathrm{Mn}$, and $\mathrm{Al}$ in AMD can be attenuated by precipitation of oxyhydroxides. However, the precipitation of $\mathrm{Fe}$ and $\mathrm{Mn}$ oxyhydroxides requires oxidation of the dissolved metals. Although associated trace metals, including $\mathrm{Ni}$ and $\mathrm{Zn}$, tend to adsorb on $\mathrm{Fe}^{\mathrm{III}}, \mathrm{Mn}^{\mathrm{III}-\mathrm{IV}}$, and $\mathrm{Al}$ oxyhydroxides at 
near-neutral $\mathrm{pH}$, slow rates of oxidation limit passive treatment and metal-removal efficiency (e.g. Cravotta 2007; Watzlaf et al. 2004). Wetlands installed along Lorberry Creek (WLL) and on Lower Rausch Creek (WLR) were effective at reducing metals transport to downstream sites because they increased the time available (retention time) for $\mathrm{Fe}$ and $\mathrm{Mn}$ oxidation and provided a location for removal of the metal-rich solids. In addition, the limestone-compost substrate of the Lower Rausch Creek wetlands apparently provided for sulfate reduction and associated alkalinity production. Nevertheless, both of the wetland treatment systems promoted increases in water temperature during summer months that could have adverse effects on fish in downstream reaches.

Although this study spanned more than 10 years, extended monitoring and documentation of treatment-system maintenance in the Swatara Creek Basin could be helpful to indicate long-term performance of the treatment systems as they approach the end of their service life. The cost efficiency computed by Ziemkiewicz et al. (2003) and estimated in this paper assumed a 20 -year service life for all treatment systems and implied that treatment performance (e.g. acid removal) would be maintained for the duration. Consideration of a future service life is useful for normalizing performance results; however, the assumed 20 -year service life may be unrealistic. Declines in performance can be expected as the treatment substrate is consumed or retention time is reduced (e.g. Cravotta 2003, 2008b). Specifically, several treatment systems evaluated in this paper required major maintenance or reconstruction within 10 years of implementation. Although limestone drains may be considered passive treatment systems, which involve minimal maintenance, the ALD at the Buck Mountain discharge and the oxic limestone drains at the Orchard and Hegins discharges all required replenishment of limestone to ensure continued benefits. Furthermore, periodic flushing of precipitated solids from the limestone beds may be necessary. Because of the high level of maintenance, diversion wells are classified as a semi-passive treatment (Skousen et al. 1998). As designed, the limestone diversion wells required frequent additions of limestone and occasional clearing of pipes. Other treatments such as the limestone channel and limestone-sand dosing could require periodic replenishment of limestone, plus the wetlands could require sludge removal to maintain performance results.

\section{Summary and Conclusions}

A variety of treatment systems was installed for the neutralization of acidity and the removal of dissolved metals from AMD sources and downstream sites in Swatara Creek and its tributaries; the eight systems evaluated in this paper were installed from 1995 through 2001. Periodic measurements of flow rate and chemical concentrations upstream and downstream of each system indicated that all eight were effective at decreasing the acidity load. However, each system had unique influent and effluent characteristics, and the treatment performance varied considering the acid load removed relative to the size of the treatment system and the estimated cost of treatment. Generally, the treatment costs were consistent with results of other treatment systems presented by Ziemkiewicz et al. (2003). In summary: (1) the limestone- sand dosing was relatively simple and inexpensive to implement and had positive water-quality effects; (2) the open limestone channel generally had negligible effects on water quality and was relatively expensive; (3) the oxic limestone drain removed significantly more acidity than the limestone sand treatment but was relatively inefficient considering the amount and cost of the limestone used; (4) the ALD was effective at removing acidity at relatively low cost; (5) the two sets of limestone diversion wells were relatively expensive but effective for treating stream water during high-flow conditions; and (6) the aerobic wetlands and limestone-compost-based wetlands generally were effective at attenuating dissolved and suspended metals during base-flow conditions but were less effective during storm flow conditions. Generally, storm flow was acidic, and, as stream flow volume increases, a smaller fraction of total flow tends to be treated and (or) residence time in the treatment system will be reduced. Furthermore, during storm flow conditions, metal-rich sediments commonly can be scoured and resuspended from the streambed.

Generally, to maintain neutral $\mathrm{pH}$ during storms, additional limestone diversion wells could be constructed to begin or increase alkalinity production as the stream stage rises and/or additional or larger limestone drains could be constructed to produce greater amounts of alkalinity and enhance the buffering capacity of base flow. Nevertheless, neutralization and $\mathrm{pH}$ buffering alone will not remedy the problem of metals transport. Alkalinity-producing systems such as limestone diversion wells or limestone drains combined with wetlands could be needed to attenuate metals transport. Because of potential adverse effects on water temperature, designs for constructed wetlands and other treatments would need to consider factors such as shading, aspect, water depth, and retention time, all of which can affect temperature.

Monitoring of the untreated influent, treated effluent, and associated changes in stream water quality over a range of hydrologic conditions is needed to indicate treatment-system performance and environmental benefits. To indicate long-term performance of treatment systems, monitoring and documentation of treatment-system 
maintenance are needed for the duration of the anticipated service life. Given such long-term data, performance metrics, such as the average acid load removed as a function of treatment system size or cost, could be improved and considered by resource managers and other stakeholders involved in mine drainage remediation.

Acknowledgments This research was supported by the PaDEP and the Schuylkill Conservation District with funding from the USEPA Nonpoint Point Source National Monitoring Program, the USDOE, and the USGS Cooperative Water-Resources Program. The author is grateful to Roger J. Hornberger and Daniel J. Koury of PaDEP for their sustained support. Jeffrey J. Chaplin, Emily Eggler, Katherine Tuers Brayton, Suzanne J. Ward, Jeffrey B. Weitzel, and Kovaldas "KB" Balciauskas presently or formerly at USGS, are acknowledged for critical assistance with field work and data processing. Helpful reviews of early drafts of the manuscript were provided by Michael J. Langland, Ralph J. Haefner, J. Kent Crawford, and Kevin J. Breen of USGS, and Christopher H. Gammons of Montana Tech, and an anonymous reviewer. Any use of trade, firm, or product names is for descriptive purposes only and does not imply endorsement by the U.S. Government.

\section{References}

American Public Health Association (1998a) Alkalinity (2320)/ Titration method. In: Clesceri LS, Greenberg AE, Eaton AD (eds) Standard methods for the examination of water and wastewater, 20th edn. American Public Health Association, Washington, DC, pp 2.26-2.30

American Public Health Association (1998b) Acidity (2310)/Titration method. In: Clesceri LS, Greenberg AE, Eaton AD (eds) Standard methods for the examination of water and wastewater, 20th edn. American Public Health Association, Washington, DC, pp 2.24-2.26

Arnold DE (1991) Diversion wells-a low-cost approach to treatment of acid mine drainage. Proceedings of 12th Annual West Virginia surface mine drainage task force symposium, WV Mining and Reclamation Association, Charleston, WV, USA, pp $39-50$

Commonwealth of Pennsylvania (2002) Water quality standards. Ch 93. PA Code, Title 25. Environmental Protection, Harrisburg, pp 93.1-93.226

Cravotta CA III (2003) Size and performance of anoxic limestone drains to neutralize acidic mine drainage. J Environ Qual 32:1277-1289

Cravotta CA III (2007) Passive aerobic treatment of net-alkaline, iron-laden drainage from a flooded underground anthracite mine, Pennsylvania, USA. Mine Water Environ 26:128-149

Cravotta CA III (2008a) Dissolved metals and associated constituents in abandoned coal-mine discharges, Pennsylvania, USA: 2. Geochemical controls on constituent concentrations. Appl Geochem 23:203-226

Cravotta CA III (2008b) Laboratory and field evaluation of a flushable oxic limestone drain for treatment of net-acidic, metalladen drainage from a flooded anthracite mine, Pennsylvania, USA. Appl Geochem 23:3404-3422
Cravotta CA III, Bilger MD (2001) Water-quality trends for a stream draining the Southern Anthracite Field, Pennsylvania. Geochem Explor Environ Anal 1:33-50

Cravotta CA III, Trahan MK (1999) Limestone drains to increase $\mathrm{pH}$ and remove dissolved metals from acidic mine drainage. Appl Geochem 14:581-606

Cravotta CA III, Weitzel JB (2001) Detecting change in water quality from implementation of limestone treatment systems in a coalmined watershed, Pennsylvania. Proceedings of 8th national nonpoint source monitoring program workshop. USEPA Seminar Series EPA/905-R-01-008

Cravotta CA III, Ward SJ, Koury DJ, Koch RD (2004) Optimization of limestone drains for long-term treatment of acidic mine drainage, Swatara Creek Basin, Schuylkill County, PA. Proceedings of 2004 national meeting of the American society of mining and reclamation and 25th WV Surface Mine Drainage Task Force, pp 366-411

Cravotta CA III, Brightbill RA, Langland MJ (2010) Abandoned mine drainage in the Swatara Creek Basin, Southern Anthracite Coalfield, Pennsylvania, USA: 1. Stream water quality trends coinciding with the return of fish. Mine Water Environ. doi: 10.1007/s10230-010-0112-6

Growitz DJ, Reed LA, Beard MM (1985) Reconnaissance of mine drainage in the coal fields of eastern Pennsylvanian. US Geol Surv WRI 83-4274, $54 \mathrm{pp}$

Hedin RS, Nairn RW, Kleinmann RLP (1994a) Passive treatment of coal mine drainage. USBM IC 9389, US Bureau of Mines, Pittsburgh, p 35

Hedin RS, Watzlaf GR, Nairn RW (1994b) Passive treatment of acid mine drainage with limestone. J Environ Qual 23:1338-1345

Helsel DR, Hirsch RM (2002) Statistical methods in water resources. US Geol Surv Techniques of Water-Resources Investigations 04A3, $523 \mathrm{pp}$

Kirby CS, Cravotta CA III (2005) Net alkalinity and net acidity 2: practical considerations. Appl Geochem 20:1941-1964

Koury DJ, Hellier WW (1999) Constructed wetland for mine drainage treatment Lorberry Junction wetland project. National Association Abandoned Mine Lands Programs Conf Pennsylvania, 9 pp

Raymond PA, Oh N-H (2009) Long-term changes of chemical weathering in rivers heavily impacted from acid mine drainage: insights on the impact of coal mining on regional and global carbon and sulfur budgets. Earth Planet Sci Let 284:50-56

Skousen JG, Rose AW, Geidel G, Foreman J, Evans R, Hellier W (1998) Handbook of technologies for avoidance and remediation of acid mine drainage. National Mine Land Reclamation Center, Morgantown, p 131

Watzlaf GR, Schroeder KT, Kleinmann RLP, Kairies CL, Nairn RW (2004) The passive treatment of coal mine drainage. US DOE/ NETL-2004/1202, 72 pp

Wood CR (1996) Water quality of large discharges from mines in the anthracite region of eastern Pennsylvania. US Geol Surv WaterResour Inv Rep 95-4243, 69 pp

Ziemkiewicz PF, Skousen JG, Brant DL, Sterner PL, Lovett RJ (1997) Acid mine drainage treatment with armored limestone in open limestone channels. J Environ Qual 26:1017-1024

Ziemkiewicz PF, Skousen JG, Simmons J (2003) Long-term performance of passive acid mine drainage treatment systems. Mine Water Environ 22:118-129 